(c) JBSSR/AIM, 2018, ISSN: 2542-2812, e-ISSN: 2631-2433.

\title{
Understanding of Plagiarism through Information Literacy: A Study among the Students of Higher Education of Nepal
}

\author{
Prem Raj Adhikari ${ }^{1}$
}

\begin{abstract}
The study deals with the issues related to the contribution and the need of information literacy. This study has explored the importance of information literacy in academic work among the Nepali students of higher education. Plagiarism is the technical term for stealing someone else's intellectual property. The research examined the truth about the understanding about plagiarism and copyright issues in the use of information. This quantitative study is aligned towards positivist paradigm and adopted survey design for data collection. The population of the study was students of higher education of Tribhuvan University, Kathmandu University and Pokhara University. Two hundred and fifty-four (254) sample populations were drawn using sample size formula for data. For this purpose, simple random sampling was used to determine the number of the sample population. The sample population was selected using random sampling procedure. The data were collected using survey method and were analyzed using SPSS descriptive statistics used for the purpose of data analysis. The findings of this study showed that information literacy is important and helpful in academic works in higher education. Students of higher education rely on the internet and library for their academic resources in Nepal. The use of information literacy is expected to be the part of education to make the learning process effective. This study also focused on the use of right information in appropriate ways among the students of higher education of Nepal. Research indicated that there was lack of understanding what students know and use about the supplied information in higher education in Nepal.
\end{abstract}

Keywords: information literacy, plagiarism, higher education, sources of information

\section{Introduction}

For the scope and definition of information literacy American Library Association(2000) states: "Information literacy is a set of abilities requiring individuals to recognize when information is needed and have the ability to

1 Mr. Adhikari is an officer at Forest Research and Training Centre, Kathmandu, Nepal. Email: youprem@gmail.com 
locate, evaluate, and use effectively the needed information" (p.1). Information literacy consists of a cluster of skills that people need to cope with the information society successfully. These are the abilities to identify what information is needed and the abilities to locate, evaluate, and use information effectively to solve problems, compose discourse and make decisions, support education and research. The definitions and the scope of information literacy (IL) tend to focus on the area and concepts related to seeking, retrieving, evaluating and using of information. The information plays significant role in education in general and higher education in particular.

The concept of information literacy has emerged and developed from the efforts of organizations and scholars (Mitchell, 2007). Zurkowski (1974) is said to be the first person who introduced information literacy concept in 1974(as cited Badke, 2010). Since the early 1990'sinformation literacy has emerged as a new subject of study in European universities. It is deemed that everyone should learn the fundamental information skills to survive in today's information rich world (Travis, 2017). Since then, information literacy has been widely investigated linking with the education and other subjects. Many universities of developed countries have integrated information literacy course into their curricula to produce informationliterate citizens. Some of the universities of Nepal have also been using and practicing information literacy as a part of library and information department since 2000. Some universities of Nepal like Tribhuvan University, Pokhara University and Kathmandu University have focused on developing information literacy unit. The target of information literacy unit is to allow maximum access to the right and reliable information to the students and the users.

The continuing shift in higher education is visible in Nepali universities (Paudel et al., 2019). It has been shifting from the instructional teaching paradigm to research-based learning (Thapa, 2015). This added more responsibility to the faculty members, students and administration. These changes have produced numerous challenges of acquiring and using the information. Information literacy has been increasing as one of the tools that can be used by higher education institutions to find the way for some of these changes. Similarly, it is pointed to prepare students for handling the information properly in their academic practices. The information 
development is an important factor that influences the economics of education such as national economy and social activities, thus, it certainly affects the entire educational environment (Barnett, 2008). Information has been regarded as a valuable commodity affected by the knowledge-based economy in learning society (Bruce, 2004). In this scenario, information literacy in education has become one of the crucial issues in the context of Nepali students. It is an essential component to gain individuals the competencies to meet the needs of the evolving information society (Sun, 2002). In Nepal, people who deal with education and information have stated to discuss on information literacy and they are broadening their studies and practices in this field.

The information environment is changing throughout the world and Nepal is no exception. With the development of the information in various form and format, education is facing enormous challenges and opportunities. Therefore, this study aims to understand plagiarism through information literacy in the context of students of higher education of Nepal.

The next section deals with methodology; section 3 shows result and discussion; and finally, section 4 concludes the study.

\section{The Methodology}

This study involved the process of exploring the reality from the respondents' opinion. It was more associated towards the post positive paradigm. This research has sought the nature of reality existing in the application of information literacy in higher education. Thus, it sought reality existed in information literacy application in higher education. This study devoted to find out the knowledge to enhance information resources in higher education. To explore these, epistemological facts survey method was used.

The design of the study is descriptive concerning with primary data. The ideas concerning information literacy was explored and examined. Thus, this study is exploratory and analytical. The study designed to examine information literacy and its practice among the students of higher education in Nepal. The researcher used a survey method to collect data. The questionnaire was designed as per the instrument for the investigation. The study employed the sample survey method using a structured questionnaire. This research used quantitative data. The research relied mostly on 
numerical data. All the students who were enrolled in Higher education were taken as the population of this study.

\section{Information Collection Procedure}

Students need lots of resources to complete their higher education study and assignments. Now, most of the resources are provided by their university in different format in their library and information section. They can be accessed via computer, internet and can be accessed from the library building. This creates certain efficiencies for the students. They can save time to find their desired information as per their needs. To find the views of students about information literacy, some known statements were asked to judge their level of understanding about information literacy. In collecting the data on this part, sets of questions were asked to all selected respondents to access the knowledge about information literacy.

\section{Table 1: Use and Practice of Information Literacy by Respondents}

\begin{tabular}{|c|c|c|c|}
\hline S.N & Questions & $\begin{array}{l}\text { Responses } \\
\text { Positive(N) }\end{array}$ & $\begin{array}{l}\text { Percent of } \\
\text { Cases }\end{array}$ \\
\hline 1 & $\begin{array}{l}\text { Does your University offer user access to the library and } \\
\text { internet based information? }\end{array}$ & 250 & 98.4 \\
\hline 2 & $\begin{array}{l}\text { Are you aware of the source of information available on } \\
\text { the library and internet that subscribed from your } \\
\text { university? }\end{array}$ & 191 & 75.2 \\
\hline 3 & $\begin{array}{l}\text { Do you know how to find your desire academic } \\
\text { information from Internet or library? }\end{array}$ & 209 & 82.3 \\
\hline 4 & $\begin{array}{l}\text { Do you receive instruction on how to use resources from } \\
\text { library or internet? }\end{array}$ & 162 & 63.8 \\
\hline 5 & $\begin{array}{l}\text { Do you use a library or information resources center to } \\
\text { check out or retrieve materials? }\end{array}$ & 224 & 88.2 \\
\hline 6 & $\begin{array}{l}\text { Do you use resources in library or Internet to prepare a } \\
\text { research paper or academic work? }\end{array}$ & 227 & 89.4 \\
\hline 7 & $\begin{array}{l}\text { Do you ask a librarian, an IT specialist or a staff member } \\
\text { for help in finding information on some topic? }\end{array}$ & 183 & 72.0 \\
\hline 8 & $\begin{array}{l}\text { Do you use catalog, index, search engine or database } \\
\text { (journal articles or books) to find material on some topic? }\end{array}$ & 180 & 70.9 \\
\hline
\end{tabular}

The use and practice of information literacy depended on the personal abilities and experiences of respondent. In response of the question of user access to the library and internet based information from their university 
offered, $98.4 \%$ of the respondents noted that their university offers user access to the library and Internet based information, whereas some of respondents ignored the access to the library and internet facilities in their universities. The all studied universities and the departments are providing library and information services. It indicated that remarkable numbers of students of higher education were still considered about the supplied and source of information.

Among them, $75.2 \%$ were aware of the source of information available on the library and internet that subscribed in their university. Still, a large number of respondents were not aware about the resources that their universities offered to them. Similarly, $82.3 \%$ of respondents were known to find out the desired academic information from internet or library. Notable numbers of students did not have ideas to retrieve desire information from library and internet. In the same way, $63.8 \%$ respondents received and considerable numbers of respondents did not receive any instructions of using resources from library and internet.

In the same way, $88.2 \%$ of students use library or information resources center regarding to check out or to retrieve desire materials. It shows large numbers of students depend on library and internet. Similarly, library and internet base resources appeared as popular among $89.4 \%$ respondents to prepare a research paper or academic work. In the same way, only $72 \%$ of the respondents consulted with librarians, IT specialists or staff members of library and information department to help in finding desire information. Even significant numbers of students hardly consulted or requested for supports to get desire information. Among those respondents, $70.9 \%$ used catalog, index, search engine or database to find material, and large numbers of users, who heard about the resources but still did not use those types of searching engines to retrieve the desired information. It shows there is a lot of ground to improve the area. Understanding of information literacy skill is an important skill towards gaining access and then using the desire information in an efficient way. With proper information literacy skills, a student could decide to use right information, in right time, in right manner to his/ her study and learning process. 


\section{Result and Discussion}

\section{Ethical and Legal Use of Information}

Academic integrity and ethical use must include a values dimension as well as an acknowledgement of the legal context surrounding these complex issues (Center for Academic Integrity, 2009). For the purposes of this study, legal and ethical use are defined as the use of resources, not of one's own creation, in a manner that adheres to intellectual property right while upholding the fundamental values of honesty, trust, fairness, respect and responsibility. Ethical use means that a user respects the ideas and works of others, gives proper attribution their work (Center for Academic Integrity, 2009). This section focused on legal and ethical issues that are associated with the information literacy which helps to avoid plagiarism and copyright in their academic work maintaining quotation, citation, paraphrasing and list of bibliography and reference.

\section{Plagiarism}

To determine what students regard as plagiarism, respondents had to indicate which of the listed scenarios the students of higher education of Nepal regard as plagiarism. The table explains the understanding level of respondents on plagiarism.

Table2: Understanding of Plagiarism

\begin{tabular}{llllll}
\hline S.N. & Statements & \multicolumn{2}{l}{ Frequency } & & \\
\hline & & Yes & $\%$ & No & $\%$ \\
\cline { 2 - 6 } 1 & Copying the work of others & 232 & 91.3 & 22 & 8.7 \\
2 & Not acknowledging what you have copied & 226 & 89.0 & 28 & 11.0 \\
3 & Unethical use of intellectual property & 104 & 40.9 & 150 & 59.1 \\
4 & $\begin{array}{l}\text { Unfair use of information to create and } 103 \\
\text { communicate knowledge }\end{array}$ & 40.6 & 151 & 59.4 \\
\hline
\end{tabular}

This section indicates respondents' understanding on plagiarism and other issues surrounding the ethical and legal use of information. On the issue of plagiarism, respondents indicated their understanding of the term plagiarism as copying the works of others $232(91.3 \%)$. It reveals that failure to give credit to the works and ideas of others' is called plagiarism.

It is false to unethical use of intellectual property $(104,40.9 \%)$, majority of the students believed that but at present this statement is true in the 
educational field of Nepal. In fact, educators fall under a special category under the law known as fair use. Certain groups to use intellectual property deemed to benefit society as a whole (e.g., in schools for instructional use). However, it deliberately did not spell out the details. It showed the level of understanding towards source of information and ethical and right use of information. Majority of respondents understood that plagiarism is "not acknowledging" what they have copied $226(89.0 \%)$. This proved that it is an acknowledgement about the source of information. In the advancement of information technology, internet has made copying another person's original work without attribution easier and more tempting. But the students of higher education in Nepal understood the value of information and citation. But data still presented, remarkable numbers of students lack an understanding on clear concept of plagiarism. Plagiarism has become an issue of concern on most college, campuses and university today.

Furthermore, $103(40.6 \%)$ respondents stated that the term plagiarism is applied for the unfair use of information to create and communicate knowledge. The respondents from higher education believed that plagiarism is known as the unfair use of copyrighted works. It raised the matter of debate which involves both public and proprietary interests. It started even in our context because of the changing dynamics between the intellectual properties and the deployment of powerful and rapidly evolving communications techniques and infrastructures. It shows the different levels of understanding about plagiarism among the students. The question helped to perceive the meaning of plagiarism in the academic world of Nepal. Most of them gave similar views on their understanding of plagiarism. It was using intellectual property without acknowledging the person. It is copying information from its original and presenting the ideas without referencing the original source. Therefore, it is concluded that one has to always cite any sources with proper citation of information used.

\section{Ways of Avoiding Plagiarism}

Deliberate plagiarism is cheating (Devlin \& Gray, 2007). Plagiarism is copying the work of others and turning it as own. It is a serious academic offense. Although there are a number of styles and methods used for handling sources depending on the discipline, there are a few rules that one can avoid it. Here, it is discussed some probable instructions on how to avoid plagiarism. 
Table3: Ways of Avoiding Plagiarism

\begin{tabular}{llllll}
\hline S.N. & Statements & \multicolumn{3}{l}{ Responses } \\
\hline & & yes & $\%$ & No & $\%$ \\
\cline { 3 - 6 } 1 & Quoting authors in my work & 232 & 91.3 & 22 & 8.7 \\
2 & Understanding and avoiding being a plagiarist & 163 & 64.2 & 91 & 35.8 \\
3 & Citing source correctly & 240 & 94.5 & 14 & 5.5 \\
4 & Creating a bibliography and list of references & 236 & 92.9 & 18 & 7.1 \\
\hline
\end{tabular}

Table 3 describes the ways of avoiding plagiarism to ensure ethical and legal use of information among the higher education students in universities. According to the table, $232(91.3 \%)$ responded that they quoted authors in their work. Likewise, $163(64.2 \%)$ respondents used paraphrasing authors in their academic work.Citation gives the evidence to support the reassured work. It helps the reader find out an item that was used in the work. To avoid the illegal use of information, $240(94.5 \%)$ respondents cited source correctly. It shows the level of understanding on how to cite and summarize sources in academic activities. It also shows the trend of higher education, how to give credit to the sources they used in their academic works.

Majority of students, 236 (92.9\%) create a bibliographic list of references in their works. Abibliographic citation as a record in precise and consistent form that gives details information about an item used in academic work. To do that, majority of the respondents were using bibliographic citations to give detailed information about materials used in their academic works.

It showed the opinion of participants and existing situation of avoiding plagiarism in universities of Nepal. The overall data from the research showed that university education unlikely addressed the ways of avoiding plagiarism in Nepal, in the current context. Large numbers of students of higher education still lack the ways of avoiding the plagiarism. It indicated that there is a risk of illegal use of academic information. It suggested that there is a need of instructions to cite sources correctly and students should understand how to avoid being a plagiarist. It helped making effective use of information and avoids plagiarism.

\section{Contribution of Information Literacy}

Information literacy is increasingly important in the contemporary environment of rapid technological change and proliferating information 
resources (Armstrong, 2008). Because of the complexity of information environment, students of higher education are faced with diverse, abundant information choices in their academic studies. Information is available through libraries, resource centers, special interest organizations, media and the internet. This section deals with the contribution and skills of information literacy to access and retrieve the desired information.

Table 4: Contribution of Information Literacy

\begin{tabular}{|c|c|c|c|c|c|c|c|c|c|}
\hline \multicolumn{2}{|c|}{ S.N. Statements } & \multicolumn{2}{|c|}{ Priority } & \multirow[b]{2}{*}{$\%$} & \multirow[b]{2}{*}{$\%$} & \multirow[b]{2}{*}{4} & \multirow[b]{2}{*}{$\%$} & \multicolumn{2}{|r|}{ Total } \\
\hline & & 1 & $\%$ & & & & & 5 & $\%$ \\
\hline 1 & $\begin{array}{l}\text { Information literacy } \\
\text { contribute meaningfully } \\
\text { academic work and research }\end{array}$ & $\begin{array}{l}\text { can } 98 \\
\text { to }\end{array}$ & 38.665 & 25.621 & 8.3 & 29 & 11.4 & 41 & 16.1254 \\
\hline 2 & $\begin{array}{l}\text { Information literacy skills } \\
\text { influence academic work }\end{array}$ & can 47 & 18.566 & 26.062 & 24.4 & 48 & 18.9 & 31 & 12.2254 \\
\hline 3 & $\begin{array}{l}\text { Information literacy educa } \\
\text { and training courses shoulc } \\
\text { included in academic progra }\end{array}$ & $\begin{array}{l}\text { ation } 39 \\
\text { d be } \\
\text { am }\end{array}$ & 15.459 & 23.248 & 18.9 & 56 & 22.0 & 52 & 20.5254 \\
\hline 4 & $\begin{array}{l}\text { It helps to find rel } \\
\text { information of area of intere }\end{array}$ & lated 26 & 10.241 & 16.172 & 28.3 & 54 & 21.3 & 61 & 24.0254 \\
\hline 5 & $\begin{array}{l}\text { Information literacy is nee } \\
\text { for reliable and authentic ac } \\
\text { to the desire information }\end{array}$ & $\begin{array}{l}\text { eded } 47 \\
\text { cess }\end{array}$ & 18.568 & 26.866 & 26.0 & 31 & 12.2 & 42 & 16.5254 \\
\hline
\end{tabular}

Respondents were given some options on some information literacy elements which are considered important. Out of that the following are indicated as most important elements of information literacy. Locating and evaluating the quality of information contribute the meaningful academic works. In this section, five pre proposed statements were developed to find out the important and needed information literacy.

According to the participants' responses, information literacy can contribute meaningfully to academic work and research to generate and disseminate information, document and knowledge in universities. The first priority of this statement $(98,38.6 \%)$ showed the opinion of participants which is towards the existing situation of knowledge of information literacy in universities of Nepal. All the respondents agreed that information literacy can contribute meaningfully to academic work. The reason that academic research can be a way of practicing information literacy but cannot be 
enough and that the person's behavior towards information plays the important role which cannot be gained just academically.

The majority of the respondents (26\%) ranked the opinion "Information literacy skills can influence academic work" in the fourth position. This indicates that information literacy is not prioritized essential skill for all the students. Information literacy education and training courses should be included in academic program. The respondents ranked the statement in the second priority $(23.2 \%)$ of shows that there is need of information literacy education and training for the student of higher education. The need of the academic resources and information has not been fulfilled by the current situation of education. Information illiterate person has skills and it is obvious that the better the skills, the more successful information based activities will be performed. Being information literate helps locate and analyze the relevant information faster on a given topic and this simplifies the research process significantly.

Information literacy helps to find related information of area of interest. Majority of the respondents $(28.3 \%)$ stated that students will able to find the relevant and related information by providing information literacy education to students. Without information literacy skills, a researcher, a student would not be able to evaluate the information we receive for relevancy or accuracy. Having good Information, literacy skills also allow being efficient in searching, saving time because it helps to get the information needed much faster.

\section{Role of Information Literacy in Academic Work}

Information literacy is a helpful tool for all who deal with information. The main intention of this sub-section of the research is to examine the contribution of information literacy among the students of higher education in their academic work. It becomes more essential to learn critical thinking skills as well as ethical usage of information related ideas. In this connection, research participants were requested to express their opinion on how information literacy contributes in their education. According to the data presented in table 5, most of the participants believed that information literacy skills are helpful to recognizing their information needs 200 (78.7 $\%$ ) for their respective academic course and works. In this issue, respondents indicated the ways in which information literacy helped them in 
their academic work such as to request or ask a good question in library or internet. It means to express information need as broad or as specific as the need. These types of question might incorporate phrases or keywords. The data showed a large numbers of students of higher education of Nepal still require the skill of information need. Majority of the students of higher education of Nepal perceived evaluating critically both the information and the seeking process i.e. $222(87.4 \%)$ in this study.

Table 5: Role of Information Literacy in Academic Work

\begin{tabular}{|c|c|c|c|}
\hline S.N & Statements & (Positive) & Percent \\
\hline 1 & Recognizing my information needs & 200 & 78.7 \\
\hline 2 & Finding the needed information effectively and Efficiently & 222 & 87.4 \\
\hline 3 & $\begin{array}{l}\text { Evaluating critically both the information and the seeking } \\
\text { process }\end{array}$ & 207 & 81.5 \\
\hline 4 & Managing the information collected & 163 & 64.2 \\
\hline 5 & $\begin{array}{l}\text { Applying prior or new information to construct new } \\
\text { concepts and understanding }\end{array}$ & 196 & 77.2 \\
\hline 6 & $\begin{array}{l}\text { Understanding and acknowledging cultural, ethical, } \\
\text { legal, and social issues related the use of } \\
\text { information }\end{array}$ & 212 & 83.5 \\
\hline
\end{tabular}

This data illustrated that information literacy skills take an increasing turn among the students of higher education. It involves a wide reflection with the information seeking skills, whereas, evaluation of information occurs all up and down the process, but this is the point when the decision must be made to proceed. The participants seemed recognizing information needs and finding the needed information effectively and efficiently to be neutral 207 (81.5\%). Research participants do agree with the contribution of information literacy to make able students to think critically about contents draw conclusions based on evidence, try to generate new knowledge and share that knowledge ethically and efficiently. Meanwhile, $163(64.2 \%)$ participants pointed out that information literacy is helpful in managing the information they collected for academic interest. It showed that there still lack the knowledge of information management. For them, information management is the collection and management of information from one or more sources, use and distribution of that information. Information literacy helps to the students of higher education to managing, (i.e. control, processing and delivery) of information. 
In the views of respondents, information literacy is useful to applying prior or new information to construct new concepts and understandings 196 (77.2\%). Rests of the respondents werestill in doubt to use IL for broad understanding. In the similar way a group of respondents $212(83.5 \%)$ indicated that information literacy helped them to understand and acknowledge the cultural, ethical, economic, legal, and social issues surrounding the use of information. It showed that higher education of Nepal tended to contribute towards academic work through information literacy. The issue of information literacy with the knowledge and skills, further developed into exploring the capability and creativity of students of higher education.

\section{Significance of Information Literacy}

This section described the respondents' views on the significance of information literacy education. Information literacy education has been perceived in a variety of ways. The section provided data for the development of efficient information literacy education in a department of a higher education. It showed in-depth understanding of the current situation as well as future expectations toward information literacy. Information literacy can play a significant role in study and learning. Seven selected statements helped to provide the entire respondents to reflect about how they focused on an information literacy need. Respondents agreed (mean $=$ $3.34, \mathrm{SD}=0.57$ ) that information literacy was needed to students not in any specific level or class because it is an academic skill to use of right information. It can be concluded that, universities should develop the information literacy skills and tools to make all students capable.

Table 6: Respondents' Views on the Significance of Information Literacy

\begin{tabular}{llll}
\hline S.N & Statements & Mean & S.D. \\
\hline 1 & Information literacy is needed to undergraduates only & 3.34 & 0.57 \\
2 & It is used to keep up to date with trend in professional development & 4.16 & 0.82 \\
3 & It is subject of Librarian or IT specialist & 3.76 & 0.85 \\
4 & Information literacy is an important source for advice & 4.11 & 0.86 \\
& regarding study and learning & 3.42 & 1.3 \\
5 & Information literacy has changed my study and learning style & 3.67 & 0.88 \\
6 & It helps me to receive proper information & 3.44 & 1.22 \\
7 & Information literacy is a part of IT skill & & \\
\hline
\end{tabular}


In the context of information literacy used to keep up to date with trend in professional, the view of the respondents is seen towards agreeing strongly (mean $=4.16, \mathrm{SD}=0.82)$. It directs that the information literacy is very useful for professional development too. The statement inquires the student participants about their uses of technology. The statements were asked to understand the views towards the computer skills and information literacy skills of the student participants. Information literacy is a part of IT skill (mean $=3.44, \mathrm{SD}=1.2)$ indicates that it is also the part of IT skills. It shows that the mode of information is dominated by the information communication technology too. Without the skills of IT, one may lack behind the huge sources of information. The students necessitate a lot of technology skills and experiences to accomplish for their course study. Survey participants claimed that it helps to receive proper information (mean $=3.67, \mathrm{SD}=.88)$. It still indicated that the implication of information literacy did not appear to be in helping students think about how information is delivered and in assisting them in locating alternative sources of information that could be useful in supporting his/ her study and learning. It showed that there was huge gap between the students of higher education regarding the use of information.

The respondents opined that the idea of literacy has been changed by technology. Information literacy is now a basic skill because information is basic needs for all levels of students and learners. It is now a part of everyday life, prepares learners for self-esteem. It depends on students' needs, interests, and skill level. The survey data revealed that most of the respondents still believes that information literacy is the subject of librarians and IT specialist which the data shows (mean $=3.76, \mathrm{SD}=.85)$. It means that there is still gaps to be addressed the concept of information literacy. Information literacy provides access to technology, professional development, independent learning, improved quality in education and information. Respondents opined that information literacy offered different kinds of instructional skills. Similarly, the respondents agreed that information literacy has changed their study and learning style (mean = $3.42, \mathrm{SD}=1.3$ ) in accordance with the time and context. The information literate student retrieves information online or offline, using a variety of methods. The information literate student extracts, records, and manages the information and its sources independently. 
To draw the importance of information literacy, it is an important source for advice regarding study and learning, the consistent view (mean $=4.11, \mathrm{SD}=$ 0.86) of the respondents justified. Information Literacy Competency Standards for Higher Education, which states, the information literate student determines the nature and extent of the information needed. It indicates that an information literate student identifies a variety of types and formats of potential sources for information. It can be concluded that information literacy is important skills and instruction for all level of students. An information literate person can be prepared with some competencies. Information literacy assists learning, how to learn and, moreover, education is about learning, so it is the key to a successful learning.

\section{Difficulties to Find and Retrieving Relevant Information}

Information has been around for a long time. The issues in using, storing, retrieving, and sharing information are always discussed. Copyright, privacy and fair use have been debated for time and cases. With all its new technologies, these issues surface again. New formats, new ease of access and new applications all require that the issues surrounding the use of information be revisited. There is no doubt that information literacy plays a vital role in managing the knowledge. But there is lots of problems in the process to retrieving and dissemination of relevant information among the students of higher education of Nepal. In this regard, the research participants expressed their opinion on the issues of difficulties to find and retrieving relevant information. The quantitative analysis of their opinion is presented in Table 7.

Table 7: Difficulties to Find and Retrieve Relevant Information

\begin{tabular}{lcc}
\hline \multicolumn{1}{c}{ Sifficulties } & $\begin{array}{l}\text { Responses } \\
\text { (Positive) }\end{array}$ & Percent \\
\hline $\begin{array}{l}\text { 1. Lack of ability to identify the proper source of } \\
\text { information }\end{array}$ & 167 & 86.6 \\
$\begin{array}{l}\text { 2. No formal education on library and Internet use } \\
\text { 3. Lack of IT skills }\end{array}$ & 159 & 67.6 \\
4. Knowledge of using search engines & 197 & 64.4 \\
5. Knowledge of the principles of ethical use of 174 & 79.8 \\
information & 126 & 70.4 \\
6. Risk of plagiarism & & 51.0 \\
\hline
\end{tabular}


The ability to identify the require information from various types of resources needs a skill that is useful in their academic activities. But many students have difficulties to distinguish between scholarly, popular, trade, reviewed, and gray publications etc. Most respondents pointed out lack of ability to identify the proper source of information 214 (86.6\%). According to this response, the problem with students is not about information tools or the research process. But with giving students specific criteria for evaluating sources and reviewing information, they are likely to gain a better understanding of the differences of sources. Information literacy is useful to assist students in learning this skill.

The above data showed that a large numbers of students do not have formal education on library and internet use i.e. 167 (67.6\%). This showed that many students still do not know how to use the library and its materials which are available in different forms and formats. Some students have ever learned to use a periodical database or an on-line catalog. Unless they are taught how and why about the use of library and internet for resources, they are likely to use random web sites and bookshelf for their information need, thinking that one source is as good as another.

Respondents opined that a person must be capable of using information technology in order to be information literate. Information Technology (IT) plays crucial roles in providing library and information service to the students of higher education. The data from the respondents show that there still lack IT skills among them, $159(64.4 \%)$. There is a lot of information and resources in front of the students of higher education to update their knowledge but due to lack of IT knowledge a large numbers of students are beyond the reach of these sources of information.

The lack of searching knowledge of resources 197 (79.8\%) from libraries, internet, electronic journals and different types of online and offline databases makes them difficult to use. Finding required documents which the institutions have subscribed to, unfamiliarity with the technologies sometimes, and poor metadata were also some of the difficulties they faced in retrieving relevant information for their academic work. As mentioned in Uribe-Tirado \& Castaño-Muñoz the information literate student understands many of the economic, legal, and social issues surrounding the use of information and accesses and uses information ethically and legally. But to compare with the data by respondent that they lacked the knowledge of the principles of ethical use of information $174(70.7 \%)$. 
Plagiarism is the technical term for stealing someone else's intellectual property. If students cut and paste something created by someone else and do not give credit to the creator, they are plagiarizing. They mentioned the fact that there is risk of plagiarism126 $(51.0 \%)$ to use the different source and resources of information. In colleges, universities and research institutions, plagiarism can cause big problems. In the context of Nepal, the electronic environment has changed the way people use information and has made it very difficult to attribute credit to the creator and very easy to borrow the information without acknowledgment.

\section{Concluding Remarks}

If students cut and paste something created by someone else and do not give credit to the creator, they are plagiarizing. In colleges, universities, and research institutions, plagiarism can cause big problems (Kauffman \& Young, 2015).In this respect; it is observed that information literacy is needed for reliable and authentic access to the desire information. Traditional literacy skills are gradually shifting to information literacy skills. As majority of the respondents (68.6\%) argued that information literacy skills help to find out the relevant information of the area of interest. Information literacy helps to interact with information to fulfill academic work and also to make efficient and effective use of information to avoid information overload. Information literacy helps in identifying gaps in research and to find the relevant resources that help to contribute to new knowledge to fill existing gaps.

\section{References}

Armstrong, I. (2008). Victorian Glassworlds: Glass Culture and the Imagination 1830-1880. Oxford University Press on Demand.

Association of College, Research Libraries, \& American Library Association. (2000). Information literacy competency standards for higher education. Retrieved from https://alair.ala.org/.../ACRL\%20 Information $\% 20$ Literacy\%20Competency\%20Stand

Badke, W. (2010). Foundations of information literacy: Learning from Paul Zurkowski. Online, 34(1), 48-50.

Barnett, P. (2008). Setting a strategic direction for information literacy at the university of Western Australia. In 5th International Lifelong Learning Conference, Yeppoon, CQU. Retrieved from 
http://www.library.uwa.edu.

au/_data/assets/pdf_file/0011/558929/Setting_a_strategic_direction

for_information_literacy_at_UWA.pdf

Bruce, C. (2004). Information literacy as a catalyst for educational change. Retrieved from https://eprints.qut.edu.au/4977/1/4977_1.pdf

Center for Academic Integrity. (2009). Fundamental values of academic integrity. Retrieved from http://www.academicintegrity.org/pdf/ FVProject.pdf

Devlin, M., \& Gray, K. (2007). In their own words: A qualitative study of the reasons Australian university students plagiarize. High Education Research \& Development, 26(2), 181-198.

Kauffman, Y., \& Young, M. F. (2015). Digital plagiarism: An experimental study of the effect of instructional goals and copy-and-paste affordance. Computers \& Education, 83, 44-56.

Mitchell, E. (2007). Organization as meta-literacy: Evaluating student use of metadata and information organization principles in the classroom. Paper presented at the SIG-CR workshop at ASIS\&T 2007. Retrieved from http://dlist.sir.arizona.edu/2067

Paudel, U. R., Devkota, N., Ghale, B. A., \& Adhikari, K. (2018). Communication and gender in bachelor's degree students' adjustment process: A study in Kathmandu, Nepal. Journal of Education, Society and Behavioural Science, 1-9.

Sun, P. (2002). Information literacy in Chinese higher education. Library Trends, 2(2), 210-217.

Thapa, A. (2015). Public and private school performance in Nepal: An analysis using the SLC examination. Education Economics, 23(1), 47-62.

Travis, T. A. (2017). From the classroom to the boardroom: The impact of information literacy instruction on workplace research skills. Education Libraries, 34(2), 19-31.

Uribe-Tirado, A., \& Castaño-Muñoz, W. (2012). Information literacy competency standards for higher education and their correlation with the cycle of knowledge generation. LIBER Quarterly. The Journal of the Association of European Research Libraries, 22(3). 